\title{
Inhibition of Excystment \\ of Schizopyrenus russelli Cysts in the Presence of Emetine and its Cysticidal Effect in Conjunction with Sodium Lauryl Sulphate
}

\author{
By S. A. IMAM, G. P. DUTTA and S. C. AGARWALA \\ Central Drug Research Institute, Lucknow, India
}

(Accepted for publication 3I August 1967)

\section{SUMMARY}

Excystment agents (extract of Escherichia coli, living $E$. coli and glutamic acid) failed to cause excystment of Schizopyrenus russelli cysts in the presence of either emetine or compounds I and II (structurally based on emetine). A very high percentage of the cysts excysted in the presence of the excystment agents after the removal of emetine, showing that the treated cysts were viable. Ninhydrin reaction, using a fixed amount of glutamic acid and increasing concentrations of emetine, showed progressive inhibition of colour development. This suggests the possible binding of excystment factor to emetine, thus preventing excystment. Excystment inducing property of the excystment agents could not be prevented in the presence of carbarsone. When the cysts were treated with sodium lauryl sulphate and then with emetine or with sodium lauryl sulphate and emetine together, there was hardly any excystment. Sodium lauryl sulphate rendered the cyst wall permeable to emetine and the latter killed the cysts.

\section{INTRODUCTION}

Relapses encountered commonly in the treated cases of human intestinal amoebiasis seem to be due to the in vivo persistence of cysts of Entamoeba histolytica which escape the action of drugs. Known amoebicides appear to have little or no effect on the cystic stage of $E$. histolytica. $5 \%$ emetine $\mathrm{HCl}$ and yatren were found to have no effect on the cysts of $E$. histolytica treated for $30 \mathrm{~min}$. in vitro (Yorke \& Adams, 1926). It is, therefore, important to discover drugs that are, in addition to having amoebicidal property, cysticidal or prevent amoebae from forming cysts or make the amoebae come out of the cysts. This question has not, so far, seriously attracted the attention of biologists and chemists engaged on the chemotherapy of intestinal amoebiasis.

Excystment of cysts of free-living amoebae and Entamoeba histolytica in the presence of certain living bacteria has been noted by several workers (Crump, I950; Drozanski, 196r; Dudziak, 1955; Kunicki-Goldfinger et al. 1957; Singh, and his co-workers, 1956, 1958, 1963, 1965.). Singh, Mathew \& Anand (1958) and Singh, Saxena \& Iyer (1965) found that an aqueous extract of an Aerobacter sp. and Escherichia coli caused excystment of five species of free-living amoebae. It was further shown by them that certain amino acids present in the aqueous extract were responsible for the excystment of Schizopyrenus russelli cysts. Certain chemically pure amino acids, at suitable $\mathrm{pH}$ range, were also found to cause excystment of 
$S$. russelli cysts. These observations have been confirmed by Drozanski (196I) in the case of free-living amoebae.

In this communication the work carried out on the inhibition of excystment of Schizopyrenus russelli cysts in the presence of emetine and its cysticidal effect in conjunction with an anionic surfactant sodium lauryl sulphate is presented.

\section{METHODS}

Cysts from a 'pure line' culture of Schizopyrenus russelli were used in this work. The amoebae were grown on non-nutrient agar $(2.5 \%$ (w/v) agar, $0.5 \%(w / v) ~ N a C l$; pH 6.8-7.0) plates supplied with a young culture (3 days old) of Escherichia coli, grown on nutrient agar slopes, as food. Three- to seven-day-old cysts were harvested and viable sterile cysts, free from living and dead bacteria, were obtained by the method of Singh et al. (I965). For excystment experiments, living $E$. coli cells, autoclaved aqueous extract of $E$. coli or L-glutamic acid $(2 \%(\mathrm{w} / \mathrm{v}), \mathrm{pH} 6.0)$ were used either singly or with emetine, compounds I and II, or carbarsone. Fifty to seventy-five cysts were put as a hanging drop suspension in a cavity slide $\left(25^{\circ} \pm I^{\circ}\right)$ and $\%$ excystment was calculated from the count of the amoebae and the unexcysted cysts. It may be pointed out that $S$. russelli forms a double-walled cyst and excystment takes place in two stages. First, the inner wall disappears and a small amoeba moves freely within the outer wall. In a successful case, the outer wall gives way and the amoeba emerges (Pl. I, fig. I-3). A cyst was considered excysted only when an amoeba escaped from it and was found moving freely in the surrounding medium.

Free amino acid available for excystment in mixtures of amino acid (glutamic acid) containing different concentrations $(\mathrm{w} / \mathrm{v})$ of emetine- $\mathrm{HCl}(62.5-1000 \mu \mathrm{g} . / \mathrm{ml}$.) or compounds I and II (1000 $\mu \mathrm{g} . / \mathrm{ml}$.) or carbarsone (1000 $\mu \mathrm{g} . / \mathrm{ml}$.) was observed by ninhydrin reaction. Emetine- $\mathrm{HCl}$ and carbarsone used were from Burroughs Wellcome and Co., and compounds I (4- $(\beta$-phenylethylaminomethyl)I-phenylethyl piperidine) and II (4-(6,7-dimethoxy I,2,3,4 tetrahydro-I-isoquinoliomethyl) I- $\beta$-3,4dimethoxy-phenylethyl piperidine) were synthesized in the Chemistry Division of this Institute as potential amoebicidal agents based on the structure of emetine.

Cysts were treated with different concentrations of sodium lauryl sulphate (made in water or $\mathrm{M} / \mathrm{I} 5$ phosphate buffer, $\mathrm{pH} 7 \cdot 0$ ) followed by emetine or together with emetine. Cysts treated individually with emetine or sodium lauryl sulphate were always included as controls. The treated cysts were washed with double glass distilled water, and the $\%$ excystment was determined.

\section{RESULTS}

The data presented in Table I clearly show that aqueous extract of Escherichia coli, live $E$. coli and glutamic acid failed to cause excystment of Schizopyrenus russelli cysts in the presence of emetine. With $E$. coli extract, excystment was observed to the extent of $89 \%$, whereas in the presence of emetine- $\mathrm{HCl}$ (I $26 \mu \mathrm{g} . / \mathrm{ml}$.) the $\%$ excystment was only 6 . When the emetine concentration was $1000 \mu \mathrm{g} . / \mathrm{ml}$., there was no excystment. These cysts did not show any excystment in the presence of emetine on prolonged incubation for $48,72,96$ and $144 \mathrm{hr}$. Morphologically the treated cysts seemed to be normal (Pl. I, fig. 4). In $62.5 \mu \mathrm{g}$. $/ \mathrm{ml}$. emetine the cysts were found to excyst in high proportion. It may be mentioned that addition of emetine- $\mathrm{HCl}$ did not appreciably 
alter the $\mathrm{pH}$ of the bacterial extract from its original value of 6.5 . Once emetine was washed off, a very high percentage of the cysts excysted in the presence of $E$. coli extract (Table I).

Living Escherichia coli cells also failed to cause excystment in the presence of emetine- $\mathrm{HCl}(1000 \mu \mathrm{g} . / \mathrm{ml}$.). The cysts appeared normal (Pl. I, fig. 5) and nearly all the cysts excysted readily in the presence of living $E$. coli when emetine was removed.

Table I. Inability of excystment inducing agents to cause excystment of Schizopyrenus russelli cysts in the presence of emetine*

\begin{tabular}{|c|c|c|c|}
\hline Cysts treated with & $\begin{array}{l}\text { No. of } \\
\text { cysts }\end{array}$ & $\begin{array}{l}\text { No. of } \\
\text { cysts } \\
\text { excysted }\end{array}$ & $\begin{array}{c}\% \\
\text { excystment }\end{array}$ \\
\hline E. coli extract & 166 & 148 & 89 \\
\hline $\begin{array}{l}\text { Emetine (1000 } \mu \mathrm{g} . / \mathrm{ml} .) \text {; excystment with } \\
E . \text { coli extract after removal of emetine }\end{array}$ & 183 & 180 & 98 \\
\hline $\begin{array}{l}E \text {. coli extract }+ \text { emetime }(1000 \mu \mathrm{g} . / \mathrm{ml} .) \\
\text { Excystment with } E \text {. coli extract after the } \\
\text { removal of emetine }\end{array}$ & $\begin{array}{l}443 \\
45 \mathrm{I}\end{array}$ & $\begin{array}{l}\text { Nil } \\
410\end{array}$ & $\begin{array}{r}\text { Nil } \\
9 \mathrm{I}\end{array}$ \\
\hline $\begin{array}{l}\text { E. coli extract }+ \text { emetine }(125 \mu \mathrm{g} . / \mathrm{ml} .) \\
\text { Excystment with } E \text {. coli extract after the } \\
\text { removal of emetine }\end{array}$ & $\begin{array}{l}254 \\
157\end{array}$ & $\begin{array}{r}14 \\
140\end{array}$ & $\begin{array}{r}6 \\
89\end{array}$ \\
\hline Live $E$. coli & 300 & 294 & 98 \\
\hline $\begin{array}{l}\text { Live } E \text {. coli }+ \text { emetine }(1000 \mu \mathrm{g} . / \mathrm{ml} .) \\
\text { Excystment with live E. coli after the } \\
\text { removal of emetine }\end{array}$ & $\begin{array}{l}599 \\
494\end{array}$ & $\begin{array}{l}\text { Nil } \\
494\end{array}$ & $\begin{array}{l}\text { Nil } \\
100\end{array}$ \\
\hline $\begin{array}{l}\text { Glutamic acid }(2 \%, \mathrm{pH} 6 \cdot 0) \\
\text { Glutamic acid }(2 \%, \mathrm{pH} 6 \cdot 0)+\text { emetine } \\
\text { (I000 } \mu \mathrm{g} . / \mathrm{ml} .)\end{array}$ & $\begin{array}{l}150 \\
590\end{array}$ & $\begin{array}{l}\text { I28 } \\
\text { Nil }\end{array}$ & $\begin{array}{r}85 \\
\text { Nil }\end{array}$ \\
\hline $\begin{array}{l}\text { Excystment with glutamic acid after the } \\
\text { removal of emetine }\end{array}$ & 418 & 384 & 92 \\
\hline
\end{tabular}

* The cysts were treated for $24 \mathrm{hr}$ with emetine alone or with emetine and excystment agents together.

Glutamic acid gave an excystment of $85 \%$, whereas glutamic acid containing emetine- $\mathrm{HCl}(1000 \mu \mathrm{g} . / \mathrm{ml}$.) showed no excystment during a period of $72 \mathrm{hr}$. After the removal of emetine, these cysts could excyst normally ( $92 \%)$ with fresh glutamic acid (Table I). Lower concentration of emetine- $\mathrm{HCl}(\mathrm{I} 25 \mu \mathrm{g}$. $/ \mathrm{ml}$.) in glutamic acid, however, did not inhibit excystment but only delayed the excystment process. Nearly all the cysts excysted within $48 \mathrm{hr}$. Still lower concentration of emetine- $\mathrm{HCl}(62 \cdot 5 \mu \mathrm{g} . / \mathrm{ml}$.) did not affect the excystment in the presence of glutamic acid.

Ninhydrin reaction was run in a parallel experiment and a progressive inhibition of colour development was noticed when increasing amount of emetine were added to a fixed amount of glutamic acid. When this in vitro system was run chromatographically (butanol + acetic acid + water: $4+\mathrm{I}+5$ ) emetine and glutamic acid could be completely separated.

Compounds I and II (I000 $\mu \mathrm{g}$. $/ \mathrm{ml}$.) also completely inhibited the excystment of Schizopyrenus russelli in the presence of Escherichia coli extract up to $72 \mathrm{hr}$. When they were removed, nearly all the cysts excysted in the presence of $E$. coli extract. In this respect the action of these compounds was like that of emetine- $\mathrm{HCl}$, although they have 
not proved to be amoebicidal. It may be mentioned that carbarsone (I000 $\mu \mathrm{g} . / \mathrm{ml}$.) did not inhibit but only delayed excystment in the presence of $E$. coli extract.

Cysts treated with sodium lauryl sulphate at dilutions of 500,250 and $125 \mu \mathrm{g} . / \mathrm{ml}$. (in $\mathrm{M} / \mathrm{I} 5$ phosphate buffer, $\mathrm{pH} 7 \cdot 0$ ) for $\mathrm{I} \mathrm{hr}$, and washed in double glass-distilled water, gave 74,79 and $76 \%$ excystment respectively in the presence of aqueous extract of Escherichia coli (Table 2). The \% excystment of the untreated cysts was 95 (Table 2). When the cysts were treated with emetine (I000 $\mu \mathrm{g} . / \mathrm{ml}$.) for $24 \mathrm{hr}$. after sodium lauryl sulphate $(500 \mu \mathrm{g} . / \mathrm{ml}$.) treatment, and washed in distilled water, there was hardly any excystment (Table 2).

Table 2 Lethal effect of emetine on cysts of Schizopyrenus russelli treated with sodium lauryl sulphate followed by emetine

\begin{tabular}{|c|c|c|c|c|c|c|}
\hline \multirow[b]{2}{*}{ Treatment } & \multicolumn{3}{|c|}{$\begin{array}{l}\% \text { excystment after sodium } \\
\text { lauryl sulphate treatment } \\
\text { for } 1 \mathrm{hr}\end{array}$} & \multicolumn{3}{|c|}{$\begin{array}{l}\% \text { excystment after sodium lauryl } \\
\text { sulphate treatment for } 1 \mathrm{hr} \text { followed } \\
\text { by emetine }(1000 \mu \mathrm{g} . / \mathrm{ml} \text {.) for } 24 \mathrm{hr}\end{array}$} \\
\hline & $\begin{array}{l}\text { No. of } \\
\text { cysts }\end{array}$ & $\begin{array}{l}\text { No. of } \\
\text { cysts } \\
\text { excysted }\end{array}$ & $\begin{array}{c}\% \\
\text { excyst- } \\
\text { ment }\end{array}$ & $\begin{array}{l}\text { No. of } \\
\text { cysts }\end{array}$ & $\begin{array}{l}\text { No. of } \\
\text { cysts } \\
\text { excysted }\end{array}$ & $\begin{array}{l}\% \\
\text { excyst- } \\
\text { ment }\end{array}$ \\
\hline $\begin{array}{l}\text { Sodium lauryl sulphate }(500 \mu \mathrm{g} . / \mathrm{ml} .) \\
\text { Sodium lauryl sulphate }(250 \mu \mathrm{g} . / \mathrm{ml} .) \\
\text { Sodium lauryl sulphate }(125 \mu \mathrm{g} . / \mathrm{ml} .) \\
E \text {. coli. extract (control) }\end{array}$ & $\begin{array}{l}334 \\
213 \\
489 \\
538\end{array}$ & $\begin{array}{l}247 \\
168 \\
373 \\
511\end{array}$ & $\begin{array}{l}74 \\
79 \\
76 \\
95\end{array}$ & $\begin{array}{l}142 \\
157 \\
322 \\
-\end{array}$ & $\begin{array}{r}1 \\
39 \\
213 \\
-\end{array}$ & $\begin{array}{r}1 \\
25 \\
66 \\
-\end{array}$ \\
\hline
\end{tabular}

Table 3. Lethal effect of emetine on cysts of Schizopyrenus russelli when treated with sodium lauryl sulphate and emetine together

\author{
Treatment \\ Sodium lauryl sulphate $(62.5 \mu \mathrm{g} . / \mathrm{ml}$ ) \\ Sodium lauryl sulphate + emetine $(1000 \mu \mathrm{g} . / \mathrm{ml}$.) \\ Sodium lauryl sulphate $(31 \cdot 3 \mu \mathrm{g} . / \mathrm{ml}$.) \\ Sodium lauryl sulphate + emetine $(1000 \mu \mathrm{g} . / \mathrm{ml}$.) \\ Sodium lauryl sulphate $(15.6 \mu \mathrm{g} . / \mathrm{ml}$.) \\ Sodium lauryl sulphate + emetine $(1000 \mu \mathrm{g} . / \mathrm{ml}$. $)$ \\ E. coli extract (control)
}

Sodium lauryl sulphate in phosphate buffer. $\%$ excystment after $48 \mathrm{hr}$.

$\begin{array}{ccc}\begin{array}{c}\text { No. of } \\ \text { cysts }\end{array} & \begin{array}{c}\text { No. of } \\ \text { cysts } \\ \text { excysted }\end{array} & \begin{array}{c}\% \\ \text { excyst- } \\ \text { ment }\end{array} \\ 333 & 327 & 98 \\ 457 & 4 & 1 \\ 478 & 473 & 99 \\ 609 & 5 & 1 \\ 502 & 499 & 99 \\ 560 & 21 & 4 \\ 144 & 144 & 100\end{array}$

Sodium lauryl sulphate in water.

$\%$ excystment after $48 \mathrm{hr}$.

$\begin{array}{ccc}\begin{array}{c}\text { No. of } \\ \text { cysts }\end{array} & \begin{array}{c}\text { No. of } \\ \text { cysts } \\ \text { excysted }\end{array} & \begin{array}{c}\% \\ \text { excyst- } \\ \text { ment }\end{array} \\ 149 & 146 & 98 \\ 225 & 6 & 3 \\ 219 & 212 & 97 \\ 510 & 5 & 1 \\ 118 & 116 & 98 \\ 192 & 3 & 2 \\ 189 & 187 & 99\end{array}$

In another set of experiments cysts were treated with sodium lauryl sulphate at dilution of $62 \cdot 5,31 \cdot 2$ and $15 \cdot 6 \mu \mathrm{g} . / \mathrm{ml}$. (in $\mathrm{M} / \mathrm{I} 5$ phosphate buffer, $\mathrm{pH} 7 \cdot 0$, or in distilled water) together with emetine (1000 $\mu \mathrm{g} . / \mathrm{ml}$.) for $48 \mathrm{hr}$. The cysts were then washed and the degree of excystment determined. There was hardly any excystment (Table 3). The $\%$ excystment of the cysts treated with sodium lauryl sulphate alone was similar to that of untreated cysts. The cysts appeared normal (PI. I, fig. 7) and nearly all the cysts excysted (Table 3 ).

The cysts which failed to excyst after sodium lauryl sulphate and emetine treatments stained readily in $0.125 \%(\mathrm{w} / \mathrm{v})$ aqueous solution of eosin. The protoplasm of these cysts along with the inner cyst wall was very much shrunken (Pl. I, fig. 6). 


\section{DISCUSSION}

It has been shown in the present investigation that excystment-inducing agents failed to cause excystment of Schizopyrenus russelli cysts in the presence of emetine hydrochloride and compounds I and II. The results of the ninhydrin reaction suggest a possible binding of excystment agent to emetine, whereas, by paper chromatography, the excystment agent and emetine could easily be separated. This binding may thus be mediated by weak electrostatic and van der Waal's forces, as suggested by Dhar (1959). When the cysts are treated with sodium lauryl sulphate and then with emetine or with sodium lauryl sulphate and emetine together, there is practically no excystment. This suggests that sodium lauryl sulphate renders the cyst wall permeable to emetine, the latter killing the cysts. The action of surfactant is not interfered with by the presence of emetine. These findings may have application in eliminating the cysts of Entamoeba histolytica from human carrier cases.

It is a great pleasure to express our sincere thanks to Dr M. L. Dhar, Director, Central Drug Research Institute, for his keen interest in this work. Grateful thanks are also due to Dr B. N. Singh, Scientist-in-Charge, Microbiology Division, for helpful suggestions during the course of this work and in the preparation of the manuscript. Authors are thankful to Mr L. M. P. Singh for his technical assistance throughout this investigation.

\section{REFERENCES}

Crump, L. M. (I950). The influence of bacterial environment on the excystment of amoebae from soil. J. gen. Microbiol. 4, 16.

Dhar, M. L. (1959). Perspective in chemotherapy. Symposium on Chemotherapy. p. 7. New Delhi: Council of Scientific and Industrial Research.

DrozANSKI, W. (196I). The influence of bacteria on the excystment of soil amoebae. Acta microbiol. polon. 10, 147 .

DudziaK, N. (1955). Kielkowanie i wzrest ameb w zalennosci on pokarmu bakteryjnege. Acta microbiol. polon. 4, II5.

Kunicki-Goldfinger, W. I., Drozanski, W., Blaszczak, D., Mazur, J. \& Skibinska, J. (I957). Bakterie Jako Pokaram pelzakow. Acta microbiol. polon. 6, 331.

Singh, B. N., DAS, S. R. \& SAXENA, U. (1963). A simple and reliable method for obtaining viable sterile cysts of Entamoeba histolytica from human faeces for monobacterial culture. Ann. Biochem. exp. Med. 23, 51 .

Singh, B. N., Mathew, S. \& ANAND, N. (1958). The role of Aerobacter sp., Escherichia coli and certain amino acids in the excystment of Schizopyrenus russelli. J. gen. Microbiol. 19, 104.

Singh, B. N., Mathew, S. \& SReenivasaya, M. (1956). Occurrence and nature of amoeba excystment factor produced by Aerobacter sp. Nature, Lond. 177, 621 .

Singh, B. N., SaXena, U. \& IYer, S. S. (1965). Production of viable sterile cysts of free-living amoebae and role of bacteria on excystment. Indian J. exp. Biol. 3, I IO.

Yorke, W. \& Adams, A. R. D. (1926). Observations on Entomaoeba histolytica. Ann. trop. Med. Parasit. 20, 279. 


\section{EXPLANATION OF PLATE}

All the photographs were taken at the same magnification.

Fig. I. Normal cyst of Schizopyrenus russelli with double cyst wall.

Fig. 2. Cyst of $S$. russelli undergoing excystment in $E$. coli extract; inner cyst wall has disappeared and motile amoeba is seen inside the outer cyst wall.

Fig. 3. A motile trophozoite of $S$. russelli after emerging from cyst.

Fig. 4. Cyst of $S$. russelli in Escherichia coli extract+emetine (1000 $\mu \mathrm{g} . / \mathrm{ml}$.) for $24 \mathrm{hr}$; appearance normal.

Fig. 5. Cysts of $S$. russelli in the presence of living $E$. coli +emetine (1000 $\mu \mathrm{g} . / \mathrm{ml}$.) for I44 hr; appearance normal.

Fig. 6. Cysts of $S$. russelli treated with sodium lauryl sulphate $(62 \cdot 5 \mu \mathrm{g} . / \mathrm{ml}$.) and emetine (I000 $\mu \mathrm{g} . / \mathrm{ml}$.) together for $48 \mathrm{hr}$; the protoplasm along with inner cyst wall is very much shrunken.

Fig. 7. Cyst of $S$. russelli treated with sodium lauryl sulphate $(62.5 \mu \mathrm{g} . / \mathrm{ml}$.) for $48 \mathrm{hr}$; appearance normal. 

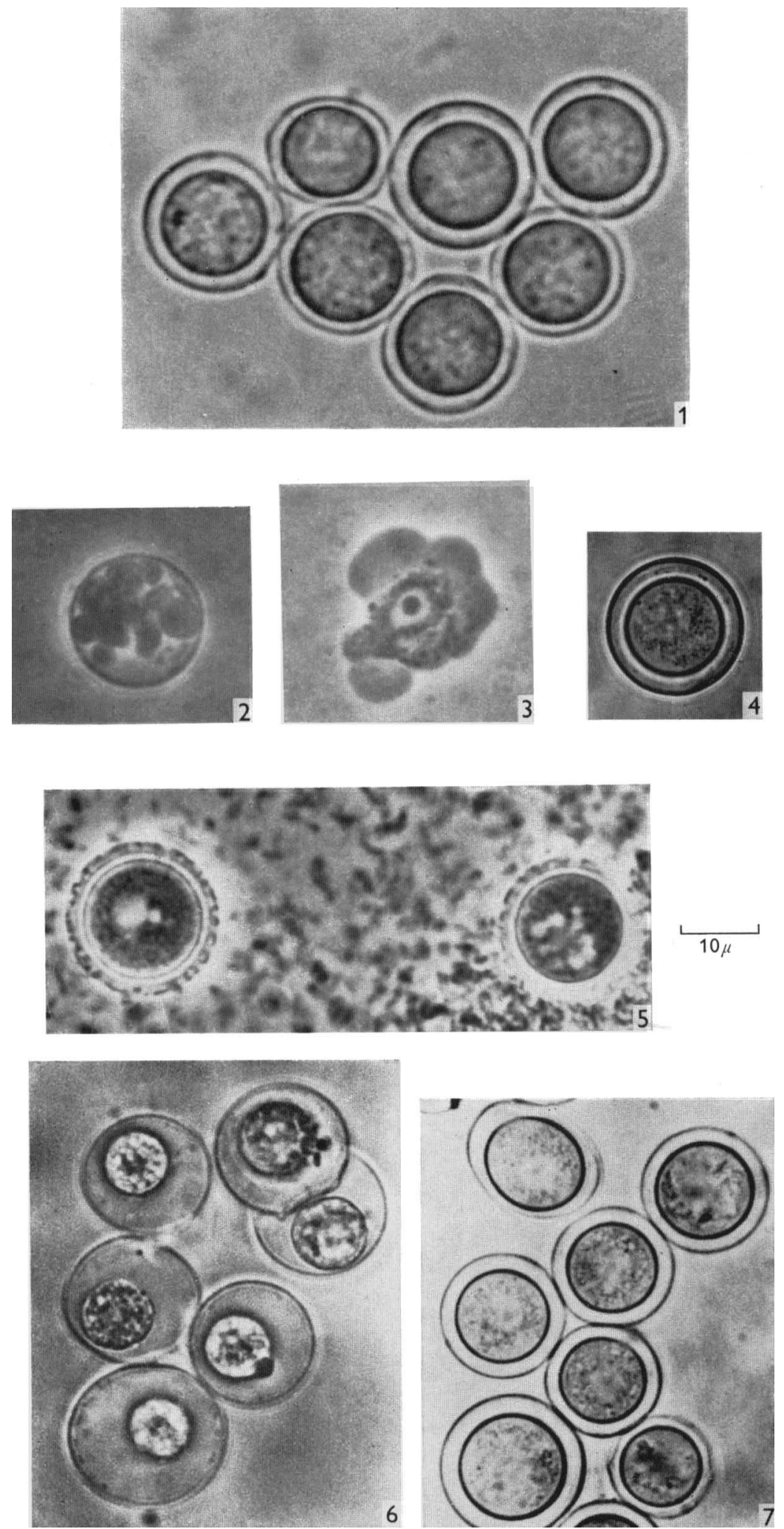